\author{
MARTA CRICKMAR \\ Uniwersytet Gdański \\ Politechnika Koszalińska \\ marta.crickmar@gmail.com
}

\title{
Tartan Polonaise: Scottish Crime Fiction in Poland
}

\begin{abstract}
This paper examines the position of contemporary Scottish crime fiction in the Polish polysystem. It investigates the definition of tartan noir and the challenges the genre poses in translation. Such concerns seem especially valid in the case of Denise Mina in whose Paddy Meehan series, next to the female protagonist, one of the most important characters is the city of Glasgow with its menacing architecture and the coarse language of its inhabitants. Thus the second part of this paper analyses the Polish translations of Mina's trilogy in order to show how the dialect and other culture-specific items have been dealt with by two Polish translators.
\end{abstract}

KEYWORDS: crime fiction, Scottish fiction, tartan noir, Polysystem Theory, dialect in translation, Denise Mina, translation into Polish.

\section{INTRODUCTION: INVESTIGATING CULTURES}

A good contemporary crime novel, in parallel to unravelling the mystery of a crime, constitutes a well of insights into the culture it describes. As such it might even become an object of interest for an ethnologist, as proved by a Polish scholar and crime fiction writer, Mariusz Czubaj, in a study entitled Etnolog w Mieście Grzechu (2010). Czubaj's book is a thorough compendium of information about the development of the genre, its subcategories and its main representatives. Out of the features he describes as common to all contemporary crime writing, this paper will focus on the ones that seem relevant to its translation - and in particular to the translation of the fraction of Scottish crime fiction known as tartan noir - namely, the genre's social focus and its concern with cultural identity and language. 
The article will start with a short survey of the Polish book market, with an aim to establish the position and popularity of crime literature, and, in particular, Scottish crime literature in the Polish polysystem. The survey will be followed by an introduction to Denise Mina's Paddy Meehan trilogy which has been translated into Polish by two translators. Hanna Pawlikowska-Gannon translated the first book in the series - Field of Blood (Pole krwi), whereas the other two - The Dead Hour and The Last Breath - were rendered into Polish by Maciej Świerkocki and their Polish titles are Martwa godzina and Ostatnie tchnienie. A short analysis of the translations will form the basis for some, more general, conclusions regarding the challenges involved in translating Scottish literature.

\section{CRIME FICTION IN POLAND}

Each year since 2007 the Polish Book Institute has published a report about the situation on the Polish book market (Dobrołęcki). These reports show that translations inadvertently constitute about one quarter of all the books published in Poland. Crime fiction is definitely one of the most popular genres. In fact, all the biggest publishing houses in Poland have crime novels in their catalogues; even the ones which profess to specialize in more "literary" books. What is more, according to the report from 2012, 9\% of all the books bought by Poles in 2011 were crime novels; and as much as $22 \%$ of all the books reported to have been read in 2011 were crime fiction. In fact, 9 out of 15 books on the bestseller list in 2011 belonged to the crime fiction category.

Thus, using the discourse of the Polysystem Theory, one can safely acknowledge that translated literature maintains a position close to the centre in the Polish literary polysystem; and similarly, the status of crime fiction as a genre is rather central. This does not mean, however, that all crime fiction translated from all languages would occupy the same, central position. In his seminal paper, "The Position of Translated Literature within the Literary Polysystem," Itamar Even-Zohar points out that "[a]s a system, translated literature is itself stratified" (2004: 202). From the fact that translated crime fiction holds a strong position in the Polish book market does not follow that it is also true of Scottish crime fiction.

\section{TARTAN NOIR IN POLAND}

To establish the position of Scottish crime literature in the Polish polysystem it might be helpful to look at another book by Mariusz Czubaj, co- 
authored with Wojciech Burszta and called Krwawa setka. 100 najważniejszych powieści kryminalnych (2007). This ambitious directory claims to present a list of 100 most important crime fiction novels of all times. The authors chose to only include the works that have been translated into Polish, so their ranking, even if unavoidably subjective and selective, may serve as some indication of a Polish perspective on the genre.

Unsurprisingly, almost $50 \%$ of the books listed by Burszta and Czubaj come from North America, followed by about $20 \%$ taken by British works. There are some singular representatives of Germany, Israel, Japan, Russia, Belgium and Canada on the list, as well as a few books each by Polish, French, Italian and Spanish writers. Scandinavia is the strongest of the underrepresented nationalities, with 5 out of 7 authors being Swedish. As far as Scotland is concerned, the authors list 4 crime writers: Philip Kerr, Alexander MacCall Smith, Val McDermid and Ian Rankin; unless, of course, one counts Scotland-born Arthur Conan Doyle or Ian Fleming, whose grandfather was Scottish. William McIllvenney, the father of tartan noir, is not covered in the book at all. Neither are other writers most usually associated with 'hard' literary crime, known as 'tartan noir', such as Denise Mina, Christopher Brookmyre, Allan Gurthie, Louise Wels, Quintin Jardine, Frederic Lindsay, Tom Morton, Stuart MacBride, Manda Scott or Ajay Close (cf. Gardiner 2009: 198; Marie Odile Pittin-Hédon 2009: 194; Gifford at al. 2002: 887-888).

This failure to include a more substantial Scottish contingent of crime fiction writers in the directory results from the fact that very few of them have been given a chance to be introduced to Polish fans of crime fiction. Only the Rebus books by Ian Rankin have been translated into Polish, as well Val McDermid's Tony Hill and Carol Jordan series, Logan McRea books by Stuart MacBride and Denise Mina's 'Paddy' Meehan trilogy. The Scottish nationality of these writers is usually hinted at on book covers and in reviews, however, there is no indication whatsoever that they are a part of a bigger group. Thus, 'tartan noir' is not a notion acknowledged by Polish publishers and, in consequence, remains unknown to the Polish readership.

Yet, elsewhere, tartan noir is a recognised, even if loosely defined, label, whose representatives "go beyond previous Scottish and British versions of the genre, using crime and the drama of urban corruption to emphasise the legacy of industrial decline and postimperial isolation" (Gifford at al. 2002: 887). The characteristics of their prose include "bleak, vicious stories of murders and rapes set in a Scotland not endorsed by the tourist board" (Innes), as well as "a down-to-earth quality, an unflinching eye on the social context of crime, a focus on the bleakly, blackly comic side of life and death" (Johnstone). 
Of course the number of Scottish works translated into Polish is only a partial indication of how well Scottish literature is represented in Poland. What is even more important is the way these books have been transferred, and especially the way the particularities of the language and culture of Scotland have been rendered in translation. In order to resolve these questions a more qualitative research is required. Let us then look more closely at the translations of Denise Mina's 'Paddy' Meehan series.

\section{PATRICIA MEEHAN TRILOGY}

Denise Mina's second trilogy is set in Glasgow, and follows the story of Patricia Meehan, a young aspiring journalist, turned night shift reporter, and finally a featured columnist on the Scottish Daily News. The first book of the series, Field of Blood is set in the turbulent period of the 1980s. The novel is named after the field that Judas bought with the thirty pieces of silver he earned by betraying Jesus. In the eyes of her staunchly Catholic Irish family, the young protagonist of the novel is also a traitor. Her parents would rather see her married to her decent Catholic boyfriend, Sean Ogilvy, than pursue a career in journalism. Paddy, however, is fascinated with the city's nocturnal, seamier side. When Sean's relative gets accused of murder, Paddy alone distrusts the police's hasty judgments and sets out on a dangerous mission to find the truth.

In the next book from the series, The Dead Hour, set in 1984 and "mixed with the gritty descriptions of housing estates and unemployed shipyard workers" (Pittin-Hédon 2009: 199), Paddy is already a reporter, but her new position does not live up to her expectations. She works night shifts and, as a young girl in a man's world, she gets little respect from her colleagues and police officers with whom she should cooperate. Unintentionally, she becomes part of a large scandal involving the murder of a lawyer and police corruption, the solving of which finally helps her realise her career plan and become a fully-fledged journalist.

Trouble finds her again in The Last Breath, where, as a single mother and a well-known, even if not widely-respected, author of a popular, 'angry' newspaper column, she is unexpectedly thrust out of her comfort zone. When the police inform her that her ex-lover has been murdered, Paddy feels compelled to get to the bottom of the crime. And even though the Glasgow of early 1990s is no longer "a byword for deprivation and knifewielding teenage gangs" (Mina 2007b: 28), her investigation leads her again into some dark places, where she has to face dangerous people, who threaten not only herself but also her family. 


\section{SOCIALLY-CONSCIOUS NOIR}

Most tartan noir novels are set either in Edinburgh or in Glasgow. The authors who base their stories in Edinburgh, write against the traditional image of the "genteel" capital, popularized by such novelists as Joan Lingard. Denise Mina, however, belongs to the latter, Glasgow-centred, fraction of writers who gladly confirm and exaggerate the idea of Scotland's biggest city as "a vast slum, a frighteningly vicious place populated by gangsters $(. .$.$) " with its crime centre in the infamous district called Gorbals - "an in-$ ferno unfit for human habitation" (Bold 1983: 230).

Social concerns seem to be especially important to tartan noir writers. In fact, as the authors of Scottish Literature emphasize, it is this ability of contemporary Scottish crime fiction to tackle social issues that allows critics to treat is as 'serious' literature worthy of academic attention; and they, reluctantly, admit that even though crime fiction does not normally represent high quality, "since McIllvenney's Laidlaw series it is recognized that exceptions exist, wherein crime is used as metaphor for modern society" (Gifford at al. 2002: 977).

Denise Mina, who wrote her first book while completing a PhD on ascription of mental illness to female offenders, found that crime fiction "gives currency to ideas on a subliminal, populous level, so that they are absorbed into the culture in immeasurable ways" and it "is a potent social force" (Pittin-Hédon 2009: 198).

Such a didactic attitude to writing must have its implications on translation. For the translator it normally means more research, as the dynamics among the characters has to be considered within a wider, socio-cultural context. Sometimes, however, this approach can actually make the translator's job easier. After all, the crime fiction writers pursuing the educational path want to make sure their message is understood by all. Mina's prose brims with information about the lives of Irish Catholics in Glasgow in the 1980s, the social unrest under the government of Margaret Thatcher, the situation of women in work places dominated by men, etc. Some of the historical details she gives as a background to her plot could potentially pose a translation problem and force the translator into employing some kind of explication technique. Yet, most of the time Mina herself provides detailed explanations of various culture-specific items, thus relieving the translators of their problems, as illustrated by the following fragment, where the name of a shipyard is mentioned in a dialogue and immediately commented on by the 'foreign reader-friendly' narrator:

Scot Lithgow shipyard was about to shut and when it did thousands of workers knew there were no jobs waiting for them elsewhere. The dole money was so low it 
was effectively a life sentence. Mrs Thatcher had publicly insulted the workers and when a committee of wives travelled to London with a petition she'd refused to meet them. Nor would the deputy prime minister or the chancellor (2007a: 108-109).

\section{LANGUAGE IN DENISE MINA'S BOOKS}

What makes Mina's Glasgow setting authentic are not only the detailed and vivid descriptions of the city's bleak architecture, supplemented with social and historical commentary, but also the vernacular of her characters. Language, of course, constitutes a very vital part of the Scottish identity and plays a prominent role in Mina's novels. It defines the status of the characters in the society, informs others about their religion and the political fractions they support. The words a person chooses can make them sound unsophisticated and laughable. Or, on the contrary, they may give them a certain authority and make them appear attractive.

Paddy often bonds with characters who are not native to Glasgow, and whose outsider status is reflected in their speech. In The Last Breath, she makes friends with an Irish pathologist, who within her first week in a new job, manages to offend half of the people she works with due to her foul tongue. While in The Dead Hour, young Paddy is especially fond of an elderly officer, McDaid, whose appearance in the novel is very brief, but still long enough to establish that his native tongue is Gaelic.

When it comes to dialect, Mina's novels appear, at first sight, to be written mostly in standard English, with only occasional Scots words inserted in the text. Following the convention common to many contemporary Scottish novels, Scots elements in Mina's trilogy are generally absent from the narrative framework and confined "largely to the dialogue of all or some of the characters" (Corbett 1997: 144).

There is no doubt, however, that the novel is populated by Scottish characters. Sentence structure, word order, the preference for certain words and colourful abuses shouted by journalists - all contribute to the feeling of 'Scottishness.' One reads it and imagines the characters speaking with Glaswegian accents. This ephemeral, emotional aspect of Scots has been commented on many times. Aniela Korzeniowska hints at it in her article on untranslatability of three Scottish writers (2004), while David Purves goes as far as to say that "the difference between the emotional quality (the 'feel') of authentic Scots and English is palpable" (2001: 11).

Korzeniowska demands that one "does not negate the fact that the people of Glasgow do have their own voice, expression and speech forms, and they are unique" (2004: 96). The Polish scholar recognises their dialect as the 
symbol of their identity that must be translated. And yet, translating dialect is one of the most challenging problems encountered time and time again by literary translators around the world.

\section{TRANSLATING SCOTS}

The Polish translators tackle the dialectal elements in Mina's novels with mixed success. They both render Scots lexemes as colloquial Polish. What is interesting is that the translations seem at times more vulgar than the original. For example the neutral Scots word 'lassie' (2011: 10) has been translated into "dziewucha" (2008:16) - an augmentative form of the Polish word for 'a girl'; while a phrase 'wee shite' (2007a: 368), which is undoubtedly negative already in the source version, has been made somewhat more offensive in the target text by being replaced with a more expressive (and gendered) derogatory term: "głupią cipą" (2009: 355). In the typology introduced by Leszek Berezowski (1997), such shifts in meaning would probably be classified as colloquial lexicalization.

Lexicalization, however, is only one of the strategies used by Pawlikowska-Gannon and Świerkocki. Unsurprisingly, it is the strategy of neutralization that is predominantly employed by both translators. It can be most acutely observed at the word level, for example when the phrase "Ya wee bissom!" (2007b: 77) is translated into "Ach, ty mały łobuziaku!" [You little hoodlum, you!] (2010: 97). The propositional meaning of the Scots words "wee" and "bissom" - the latter listed in The Essential Scots Dictionary with an alternative spelling 'besom, bizzom' and defined as "a term of contempt for a person, especially a woman" (Cairns at al. 2004) - has been carried across but the evoked meaning, resulting from the dialectical usage, has been lost.

Above the word level, one of the features of Scots which is recurrent in the speech of Mina's characters is the characteristic use of the question tag "eh?" used at the end of a sentence, following both affirmative and negative clauses (Miller 2003: 97). This typically Scottish feature has been translated with a standard question tag "tak?" and a less formal one "co?" At times the question tag is omitted altogether, and thus remains unmarked in the translation, as illustrated in the following excerpt:

'Fiona O'Conner, how are you doing?' said Paddy, though she never liked her at school and vaguely remembered being insulted by her. 'Is this your wee one?'

Fiona raised her smarting eyes. 'Oh, yeah, hi. Help us down with the pram.'

Paddy took the front axle of the pram and lifted it down the two steps to the street.

Fiona looked annoyed. 'I thought Sean was going out with Elaine McCarron now.' 
Paddy winced a little at the mention of Elaine and wondered why she did. 'Aye, they've been together for a year now. Seem to be getting on well.'

'Oh right,' said Fiona slyly. 'You're always here, but, eh?'

Paddy gave her a stiff smile and slipped past Fiona into the close (2007b: 30-31).

- Fiona O'Conner... Jak się masz? - zapytała Paddy, chociaż w szkole nigdy jej nie lubiła i pamiętała nawet jak przez mgłę, że Fiona jej dokuczała. - To twoje maleństwo?

Dziewczyna podniosła na nią zaczerwienione, rozpalone oczy.

- Ach tak, cześć. Pomóż nam z tym wózkiem.

Paddy chwyciła pojazd za przednią oś i pomogła koleżance znieść go o dwa stopnie niżej, na ulicę, a mimo to Fiona sprawiała wrażenie poirytowanej.

- Myślałam, że Sean chodzi teraz z Elaine McCarron.

Paddy skrzywiła się nieco na wspomnienie Elaine i sama spróbowała odpowiedzieć sobie na pytanie dlaczego.

- Tak, są ze sobą od roku. I chyba jest im dobrze.

- No jasne - odparła chytrze Fiona. - A ty mimo to ciągle tu przychodzisz, co?

Uśmiechając się sztucznie, Paddy przecisnęła się obok na podwórko (2009: 29).

The above-quoted fragment is especially interesting from the linguistic point of view. First of all, in addition to Scots words such as 'wee' and 'aye,' and the characteristic question tag, it comprises an unusual structure 'give us,' where the pronoun 'us' is used instead of 'me' which would be required in this context by Standard English grammar. Jim Miller explains that in Scots " $[u] s$ is generally used instead of me, particularly with verbs such as give, show and lend (...)" (2003: 75). The translator, apparently unfamiliar with this feature of Scots, mistranslates Fiona's sentence into Polish, rendering the Scottish "us" meaning 'me' into Polish "nam" meaning 'us,' thus suggesting the presence of some (at least one) additional person (other than the baby in the pram, of course) at the scene, in need of Paddy's assistance.

Another dialectal element in the dialogue between Paddy and Fiona is the unusual, from the Standard English perspective, structure of the sentence: "You're always here, but, eh?'". The non-standard word order, with "but" at the end of the clause have been rendered into standard, unmarked, Polish ("A ty mimo to ciągle tu przychodzisz, co?"). In fact, the structure is translated this way each time it appears in the source text.

Another subtle difference between Scots and Standard English which features prominently in Mina's representation of the way Glaswegians speak is the usage of the definite article before nouns denoting family relatives (Miller 2003: 99), as evident in the following fragment:

She caught Tam's eye as she approached the panda car.

'Meehan,' he said.

'All right, Tam? Is that you back from your holidays?' 
'Aye.'

'Nice time?'

'Two weeks with the wife and a six-month old wean,' sneered Tam. 'You work it out' (2007: 14).

Podchodząc do wozu patrolowego, kątem oka złowiła spojrzenie Tama.

- Cześć, Meehan - powiedział Tam.

- Co u ciebie? Wróciłeś już z wakacji?

- Owszem.

- Fajnie było?

- Spędziłem dwa tygodnie $\mathbf{z}$ żoną i sześciomiesięcznym berbeciem, więc sama sobie odpowiedz na to pytanie - odparł sarkastycznie Tam (2009: 12).

As in all the instances analyzed so far, the non-standard element has been neutralized in the translation, which is hardly surprising, given the fact that the Polish grammatical system lacks articles.

In addition to neutralizing the dialectal aspect of the text, the renditions of dialect in Polish translations of Mina's books are sometimes simply awkward. Especially the common Scots word "wee" ('small, tiny, little') seems problematic in translation. Its literal translation into Polish may result in unintentionally artificial or comical sentences. And finally, it can even change the undertone of the exchange between the characters. For example, in the fragment quoted below the phrase "wee hen" spoken by a police officer is likely meant to be friendly and fatherly, the word "hen" being defined by The Essential Scots Dictionary simply as a "term of address for a girl or woman."

'I don't think biscuits keep you awake,' he said. 'But wire in, wee hen. We need to speak to someone' (2007b: 110).

Moim zdaniem herbatniki nie działają pobudzająco na organizm - powiedział. - Ale jedz, maleńka. My musimy jeszcze z kimś pogadać (2009: 105).

The Polish version of the officer's line with the phrase "wee hen" translated as "maleńka" ('my little (baby)girl') could easily be interpreted as inappropriate, flirtatious or even sexual, thus completely changing the mode of the conversation.

\section{CONCLUSIONS, SOLUTIONS}

In their introduction to The Edinburgh Companion to Twentieth-Century Scottish Literature, Ian Brown and Alan Riach assert that "[1]iterature is an essential way in which people in communities convey to themselves and 
others their concerns and imaginings. In twentieth-century Scotland, perhaps its greatest achievement was to convey a diversity of different Scottish identities to each other" (2009:1). What then can Polish readers learn about the "diversity of different Scottish identities," if one of the defining features of this community - its language, its accent - has been left untranslated?

It is clear that unlike the setting, the social aspect and culture-specific items discussed earlier in this paper, the languages of Scotland prove very challenging in translation. In fact, none of the Scottish/Glaswegian elements of Mina's series of novels have been reproduced in the Polish versions. When Scots words and grammatical structures appear in the original, in translation they are neutralised or made to sound dated or simply silly.

It is in fact the language used by Scottish writers that looms large behind many of the problems and controversies connected with the reception of Scottish literature abroad. Scottish voices, "thick as fruit scones and fish suppers" (Calder 2008: 190), often seem "impenetrable" (Ashley 2007: 349) to non-Scottish readers in other parts of the UK, as well as in the USA, Canada, India, South Africa and Australia. "The fundamental difficulty" - argues Ashely - "lies in reconciling an international English literature - guided by market forces of sales, distribution and 'translatability' from one English to another - with the diversity and concomitant problems of language in Scotland" (2007: 349). Ironically, it is the same "impenetrable" quality of the language that prevents English speakers from perusing Scottish books that then gets lost in translation into other languages, and, as a result, "the distinction between Scottish and English or Scottish and British writing is hazy indeed to many outsiders" (Ashey 2007: 345). As a consequence, it is tempting to put forward a thesis that, in terms of the language, some Scottish literature is 'too Scottish' for non-Scottish English speakers to understand and, in its translated versions, 'not Scottish enough' for non-English speakers to distinguish it from other British literature they import into their cultures.

Perhaps translators should start looking for alternative solutions which are not based on a straighforward 1:1 relationship (a non-standard variety into another non-standard variety, a dialect into another dialect). One such solution can even be found in the translation of Mina's works, and specifically in the following fragment from The Last Breath:

'By God, ye've some head of hair on ye,' said Paddy, letting her Irish phrasing show now they were alone (2007b: 40).

- O mój Boże, ale ty masz włosy - powiedziała Paddy, pozwalając sobie na irlandzki akcent, bo była teraz z Aoife sam na sam (2010: 50).

In this exchange Paddy is not actually speaking Scots but succumbs to her Irish roots and lets it be known by her phrasing. Her words are trans- 
lated into neutral, standard Polish, but instead of being informed about the "Irish phrasing" in Paddy's line, Polish readers learn that she spoke with an Irish accent. This information has been added by the translator, forced into such a manouevre by the difficullty with translating the dialect itself. Thus the untranslatability of the fragment accually presented the translator with an opportunity to communicate the difference inscribed in the source text, even if he had to change the focus of this difference. The reader now knows that Paddy spoke in a non-standard way - she spoke with an accent.

Of course, such a strategy has its limitations. One could say that merely informing the readers that characters speak in a dialect or with an accent would be the same as telling them that what they are reading is a word play or a joke without attempting to somehow reconstruct the said word play or joke. It is, however, a start - a footnote-like step in the direction of 'putting a kilt' on Polish translations of Scottish works or 'tartaning them up,' as journalists apparently say when they are asked to introduce a Scottish interest into a news story (Corbett 1997: 32). After all, there are a lot of wonderful Scottish books out there which need to be not only translated into Polish but also translated in such a way that would successfully communicate their Scottish identity to Polish readers. Why not start with tartan noir?

\section{REFERENCES}

Ashley, K., 2007. Scots Abroad: The International Reception of Scottish Literature. In: Schoene, B. (ed.). The Edinburgh Companion to Contemporary Scottish Literature. Edinburgh: Edinburgh University Press, 345-354.

Bold, A., 1983. Modern Scottish Literature. London-New York: Longman.

Berezowski, L., 1997. Dialect in Translation. Wrocław: Wydawnictwo Uniwersytetu Wrocławskiego.

Brown, I., Riach A. (eds), 2009. Edinburgh Companion to Twentieth-Century Scottish Literature. Edinburgh: Edinburgh University Press.

Burszta, W.J., Czubaj M., 2007. Krwawa setka. 100 najważniejszych powieści kryminalnych. Warszawa: Warszawskie Wydawnictwo Literackie Muza SA.

Cairns, P., Macleod, I. (eds), 2004. The Essential Scots Dictionary: Scots-English, EnglishScots. Edinburgh: Edinburgh University Press.

Calder, A., 2008. Scotlands of the Mind. Edinburgh: Luath Press Limited.

Corbett, J., 1997. Language and Scottish Literature. Edinburgh: Edinburgh University Press.

Czubaj, M., 2010. Etnolog w Mieście Grzechu. Gdańsk: Oficynka.

Dobrołęcki, Piotr, Rynek ksiażki w Polsce 2012. http://www.instytutksiazki.pl/upload/ Files/rynek_ksiazki_2012.pdf (date of access: 20.10.2013).

Even-Zohar, I., 2004. The Position of Translated Literature within the Literary Polysystem. In: Venuti, L. (ed.). Translation Studies Reader. London-New York: Routledge, 199-204. 
Gardiner, M., 2009. Arcades - The 1980s and 1990s. In: Brown, I., Riach A. (eds). Edinburgh Companion to Twentieth-Century Scottish Literature. Edinburgh: Edinburgh University Press, 181-192.

Gifford, D., Dunnigan, S., MacGillivray, A. (eds), 2002. Scottish Literature. Edinburgh: Edinburgh University Press.

Innes, K., Scottish crime writing. http://www.list.co.uk/article/5378-scottish-crime-writing/ (date of access: 20.10.2013).

Johnstone, D., How William McIlvanney invented tartan noir. http://www.theguardian. com/books/2013/aug/11/william-mcillvanney-tartan-noir (date of access: 20.10.2013).

Korzeniowska, A., 2004. The challenge of the non-standard and the notion of untranslatability in reference to three Scottish writers: Tom Leonard, James Kelman and William McIlvanney. In: Kubińska, O., Kubiński, W. (eds). Przekładając nieprzekładalne. Vol. 2. Gdańsk: Wydawnictwo UG, 93-100.

Miller, J., 2003. Syntax and Discourse in Modern Scots. In: Corbett, J., McClure, D., Stuart Smith, J. (eds). The Edinburgh Companion to Scots. Edinburgh: Edinburgh University Press, 72-109.

Mina, D., 2007a. The Dead Hour. London: Bentam Books.

Mina, D., 2007b. The Last Breath. London: Bantam Press.

Mina, D., 2008. Pole krwi. Warszawa: W.A.B.

Mina, D., 2009. Martwa godzina. Warszawa: W.A.B.

Mina, D., 2010. Ostatnie tchnienie. Warszawa: W.A.B.

Mina, D., 2011. The Field of Blood. London: Orion Books.

Pittin-Hédon, M.O., 2009. Scottish Contemporary Popular and Genre Fiction In: Brown, I., Riach A. (eds). Edinburgh Companion to Twentieth-Century Scottish Literature. Edinburgh: Edinburgh University Press, 193-203.

Purves, D., 2001. A Scots Grammar: Scots Grammar \& Usage. The Saltire Society. 